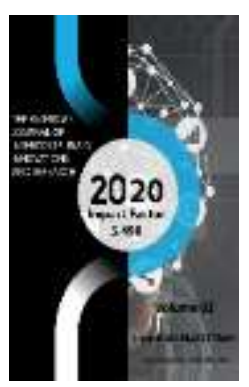

\title{
The Biography Of Abdulla Avloni, Representative Of Uzbek Literature Renaissance, From A New Perspective
}

\author{
Yulduz Akmalovna Artikova \\ Candidate Of Philological Sciences, Department Of “PR And International Communication”, \\ Faculty Of "International Journalism And Public Relations", Journalism And Mass \\ Communication University Of Uzbekistan
}

Journal Website: http://usajournalshub.c om/index,php/tajiir

Copyright: Original content from this work may be used under the terms of the creative commons attributes 4.0 licence.

\section{ABSTRACT}

This article provides a new scientific analysis of the biography of Abdulla Avloni, an enlightened poet, playwright, journalist, scientist, statesman and public figure who lived and worked in the late 19th and early 2oth centuries. It is well known that in the Soviet era, educated, enlightened people were persecuted as enemies of the people. Those who were shot, family members were politically persecuted as relatives of the enemy of the people. Most writers, scientists were forced to change their biographies, to hide their genealogy. In works of art, the aristocracy is portrayed in a negative light. The article analyzes the changes made to Abdulla Avloni's biography for political reasons on the basis of scientific sources and memoirs.

\section{KEYWORDS}

Jadidism, national development, enlightenment, literature of the national renaissance, victims of repression, Soviet policy, biography, neighborhood.

\section{INTRODUCTION}

In the study of the works of literary and artistic figures, information about the period and time in which they lived, the details of their experiences, information about their relatives and friends is of great importance. Especially if their lives and works have not been sufficiently studied with the passage of time, or if their biographies have not been approached objectively and objectively in accordance with the requirements of the time. In this regard, the fate of the representatives of Jadidism, who sacrificed their lives for the freedom of 
our country, which is the recent past, is especially in areas in need of scientific research. It is a requirement of today that this period, which marked a turning point in the history of our country due to the invasion of Tsarist Russia and the subsequent policy of the Soviet era, be painted in bright colors. Since there is no future without history, it is the duty of each of us to look at our recent past with a little calm and objectivity.

We can see that the development of a nation is inextricably linked with spirituality, enlightenment, education, and not with economics, politics or foreign relations, in the specific path of development of Japan, which has its place in world civilization. In our country, too, the brightest representatives of the nation have sacrificed their lives for such noble ideas. Abdulla Avloni is one of the brightest representatives of the Jadids, the leader of the Enlightenment movement, who saw the liberation of our nation and homeland from the mire of ignorance as the most basic necessity.

Abdulla Avloni is one of the most important figures in the history of our country as a role in the literature of the Uzbek national renaissance, his contribution to the development of Uzbek journalism, the founder of our national pedagogy and the founder of the Uzbek theater. An enlightened poet, playwright, journalist, scientist, statesman and public figure, Abdulla Avloni “.... joined the Jadid movement and became one of the active participants of the Jadids in Tashkent. In 1904, Avloni opened a new school in Mirabad, and later in Degrez, in a similarly new way, teaching and writing textbooks. (Mergancha, Degrez, the name of the mahallas of Tashkent - author.
Yu.O.) In 1909, the school opened a "Jamiyati xayriya" (Charity Society) that helped with educational work and taught orphans. He published the first volume of a four-part collection of poems entitled "Adabiyot yoxud milliy sherlar" (Literature or National Poems).

In partnership with such developers as Munavvarqori, Muhammadjon Podshokhojaev, Tavallo, Rustambek Yusufbekov, Nizomiddin Khojaev, Shokirjon Rahimi, he founded Nashriyot (1914) and Maktab (1916). He published the newspapers "Taraqqiy", "Shuhrat" (1907), “Osiyo" (1908), and “Turon” (1917). In 1918, he became one of the founders and first editors of "Ishtirokiyun", the first newspaper of the Turkestan Soviet government.

Abdulla Avloni's life is a little different from other Jadid figures. Unlike other Jadids, intellectuals, literary and artistic figures, Abdulla Avloni was not repressed, but his work, like that of all Jadids, was not studied until 1966, and his works were not published until that year. It was during this period that there were some changes in policy, and information about the victims of repression within the former Soviet states was made available to the public.

Let's talk about Abdulla Avloni's biography and rich heritage to this day. It is known from history that great men were always accompanied by wise women who supported them. Bibihanim, Nodirabegim are a clear example of this. Their wife Salomat Aya has a special place in the rich cultural heritage of Abdulla Avloni. So far, most of the rare information about this scholar is based on the manuscripts and documents submitted by his wife Salomat aya Islamova to the literary critic 
Begali Kasimov in 1966. During the years of repression, Abdulla Avloni was not denounced as an "enemy of the people," but his works were not published after his death. It is as if Abdulla Avloni, with his untimely death, has protected his honor and the peace of his family from danger. This means that in the years of repression of the last century, the policy of the former Soviet Union, like all Jadids, was "dissatisfied" with the good intentions in the works of Abdulla Avloni, and his ideas "did not fit" into Soviet policy. From 1934 to 1966, mother Salomat knew that the value of Abdulla Avloni's works would be very high in time. Those who preserved their manuscripts believed that times would change and the attitude towards the enlighteners of our country would change radically. Carrying out a number of scientific researches on the role of this faithful and loyal woman in the fate of Abdulla Avloni is one of the next tasks facing our young researchers. Although very little is known about Salomat Islamova, in order to understand Abdulla Avloni's ideas and appreciate her works, this noble woman herself was extremely intelligent, enlightened and progressive.

It is possible that Abdulla Avloni, like all intellectuals at the time, made "necessary" changes in his biography. Like everyone else, he emphasizes his social background - which he was in a simple poor peasant family, growing up in an extremely helpless situation. Abdulla Avloni's "Biography” prepared for publication by Begali Kasimov says: "I was born on July 12, 1878 , in a poor family in the Mergancha mahallah of the old city of Tashkent, Shayhantahur. My father's name is Miravlon and my mother's name is Fatima. My father's main occupation was weaving, and later he worked as a weaver at the Fair Market, trading in gray and chit" [3]. This is how all the intellectuals who lived and worked in the Soviet era defined their biographies. It was part of Soviet policy to say that our intellectuals, who contributed to science, grew up in a difficult working-class family and could only become so well-educated because of the "care and kindness" of the Soviet system and the party. As a result of such "changes", the real lives of our intellectuals are left behind.

It is known that Abdulla Avloni was one of the mature intellectuals of his time and his not only secular but also religious knowledge was highly acclaimed. Prior to the Soviet era, most intellectuals (Mir generations were mostly intellectuals) were fluent in Arabic and Persian in addition to Uzbek. If religious science is studied through Arabic, a thorough knowledge of Persian is required to have a deep knowledge of fiction. Abdulla Avloni, not from a poor peasant family, but from a welleducated family, was a man of knowledge due to his social status. In general, in addition to Uzbek, Arabic and Persian, Abdulla Avloni was fluent in Russian, Tatar, Azerbaijani and Turkish. He has skillfully translated a number of works of fiction into Uzbek. As his biography shows, Abdulla Avloni could not have grown up to be such a knowledgeable, educated, broadminded man only when he had the opportunity to receive education during the winter days. There is no doubt that he made changes to his biography in accordance with the requirements of the time. "Since the age of 7 , Akromkhan studied at the old school in Oqchi. In 1890 he moved to a madrasah in the same neighborhood. Then he studied at the Abdumalikboy madrasah in Shayhantahur, Mulla Umar Akhund .... His interest in literature 
awoke in those years. He loved Navoi's poetry and Fuzuli's ghazals. He then eagerly studied Persian. He enjoyed the world of Sa'di and Hafiz. Eventually these paid off. As he humbly noted, he "began to write poetry" [1].

If we look at history. Earlier, the city of Tashkent ended in the Anhar Canal, and after the invasion of Tsarist Russia, part of it was divided into the New City and the other into the Old City. The present name of the Old City is a name left over from that period. On the east side of the Anhar, in the Shayhantahur district, there were country houses. It is known that the prototype of Mirzarkarimboy, written in the work of our famous writer Oybek "Kutlug Kan" - Mirkarimboy is one of the great merchants of Tashkent, and his country house is located here. After the construction of the railway, the demand for Mirkarimboy's lands was high. He built and rented houses instead of his farm. Mirkarimboy's sons Mirafzal and Mirqosim inherited the houses on the site of those fields. Later, their descendants lived in these lands. Prosperous lands are called in their language "Mirabad" - "Lands prospered by the Mir". The Russians did not like (but did not understand) the concept of neighborhood. That is why the streets are called Mirabadskaya. Today the original name of Mirabad district dates back to those times. Descendants of Mirkarimboy and other "mirzas" lived here and married each other. Abulla Avloni also belonged to the Mir dynasty. His father's full name was Miravlon, and his grandfather's was Mirne'matboy. Avloni's wife, Salomat Islamova, was also a child of a wealthy aristocratic family of her time and was an educated woman. His biographers write: "In 1900, Avloni married a Tashkent merchant named Salomatkhan. His father died that year"
[1]. After the death of his father, he and his brother built a house for themselves in a country house inherited from his grandfather, and the two families became homeowners. "Mirne'matboy had a garden on the site of the current Mirabad mahalla. After the conquest of Tashkent and its transformation into the center of the Governor-General of Turkestan, Mirabad was added to the new "Russian" part of the city and allocated for the construction of various buildings and enterprises. Sapyorny, Gospitalny streets will appear. Miravlonboy's two sons, Abdulla and Mirsiddiq, also live here. "[1] That is, the Avloni brothers lived for many years in courtyards built on the site of their grandfather's country house. Their city courtyard, as Abdulla Avloni showed in his biography, was in the Merganchi neighborhood. This means that Miravlon, who owned city and country houses, was not a helpless and poor farmer. Abdulla Avloni was forced to write this in his biography at the request of the time. Unfortunately, his biographers continue this trend in line with the requirements of the time: “... But the hardships of life do not allow reading. "Beginning in 1891, I studied only in the winter and worked parttime in other seasons," Avloni writes. Soon this too was abolished. He was completely immersed in the work. As he put it, he studied "building" and was "engaged in bricklaying, plastering, stove-making, and carpentry" [1]. It should be noted that the biographers added the suffix "boy" to the names of his father and grandfather and memorized them in the form of "Miravlonboy", "Mirne'matboy". Usually no such additions are made to the name of the poor artisans. The addition of "rich" to the names of nobles and landowners adds another clarity to Abdulla Avloni's social background. Unfortunately, at the request of Soviet-era 
policy, Abdulla Avloni himself was forced to change his biography. In the Soviet era, however, this information has been accepted as a historical fact for years. Literary critics, on the other hand, were forced to make changes to the author's biography in order to allow the Soviet policy leadership to conduct scientific research into his work.

\section{RESULTS AND DISCUSSIONS}

In his autobiography, Avloni writes that many called him a "master builder". This is natural. Because the rich people of our country have always been poor and honest people. For example, Mirkarimboy was the first to bring a Zinger sewing machine to Germany from Tashkent, and his daughter Nisobibi sewed hot pants for the workers in order to be rewarded with this machine. That is, the city's big moneylenders were not only educated but also skilled, caring for the poor and needy. Such meritorious deeds have become the norm. It is possible that Abdulla Avloni was not from a helpless life, but he was not ashamed of his work as the children of the boyans of that time, he took up several trades and helped people impartially. Abdulla Avloni's later work also focused on charity. He founded the Charity Society in 1909, raising money for the education of local children and distributing it to schools. It was even reported by the Orenburgbased newspaper "Vakt" [1]. Thus, long before the advent of the Soviet regime, Abdulla Avloni began a series of laudable works in the field of charity and enlightenment. Begali Kasimov, a biographer of Abdulla Avloni, comments: "According to the 41-article Charter of the Society, approved on May 12, 1909, its goals and scope of activities were wide. Improving the material and spiritual condition of helpless, needy Muslims in the Syrdarya region (Tashkent was the capital of the Syrdarya region. - B. Q.), Including the opening of hospitals, dispensaries, cafeterias, kitchens, dormitories for orphans, the elderly, the disabled, schooling, then to foreign affairs" [1]. This means that Abdulla Avloni was originally from a noble family and, like most landowners of the time, was involved in a wide range of charitable activities. All the nobles around him financially support such charitable deeds. There is no doubt that the author's biographical handicrafts are one of such charitable deeds. Another aspect of Abdulla Avloni's social background. In Uzbekism, there are such concepts as kudachilik, "to be against kuda". That is, families belonging to the same social stratum gave and took daughters. As noted above, Abdulla Avloni's wife, Salomat Islamova, was also a child of a wealthy Tashkent aristocratic family. Based on the analysis in the article, it should be noted that although the author himself wrote the opposite in his biography due to political pressure, both Avloni's grandfather and father were wealthy landowners and merchant aristocrats of that time. Abdulla Avloni marries his eldest son, Savriniso Mirfayzi, and Miryaqub, the son of Jannatnisa. In other words, Abdulla Avloni married Mirfayzi, one of the great merchants of that time, and Jannatniso, the daughter of Mirkarimboy, one of the great landowners of Tashkent. Considering that match-maker (kudachilik) was mainly among families of equal social status, it becomes clear once again that Abdulla Avloni has long been a representative of such families in social status.

The fate of Abdulla Avloni's daughter, Savriniso, reflects the disgusting state of the 
Soviet-era political system. Her marriage to Miryokub will not last long. When his daughter Tuygunoy was two years old, Miryokub, like many intellectuals of the time, fled to Turkey to escape persecution. Savriniso is forced to return home with her two-year-old daughter. Gavhar Zokirova, the beloved artist of our country, is the daughter of Tuygunoy and the granddaughter of Abdulla Avloni. Gavhar Zokirova recalls that Abdulla Avloni advised his son-in-law to go to Turkey and save his life. Miryakub's flight from abroad was not to the liking of the political system of the time. Miryakub's father, wife, and later his daughter were constantly interrogated by PCIA officers, beaten and beaten to tell the "truth." Unable to bear this oppression, the poor father soon died. Savriniso will not live long, suffering from torture interrogations. Although Tuygunoy has not seen his father since he was two years old, he is regularly summoned for questioning before entering the institute. According to the fate of the family of Abdulla Avloni's eldest child, in order to protect himself and his family, Abdulla Avloni's rewriting of his biography should be taken as a matter of course for a period of political repression.

Abdulla Avloni had with his wife Salomat Islamova and daughters Savriniso, Karima, Kunduz, Hakima, sons Asatilla, Atalik, Kenja. Hakima, Kenja's children will serve their country for many years, preserving their father's legacy. In her house in 1212, Hakim Aya pays homage to Abdulla Avloni's belongings. In the book "Letters to my daughter" by our famous writer Olmas Umarbekov, Abdulla Avloni is mentioned with boundless love and faith. In her house in "Gospitalniy", Hakim Aya pays homage to Abdulla Avloni's belongings. In the book "Letters to my daughter" by our famous writer Olmas Umarbekov, Abdulla Avloni is mentioned with boundless love and faith. Olmas Umarbekov, like Mirkarimboy, was from Oqchi mahalla, and his house was located in Mirabad district, in the area called "Gospitalniy" at that time. Abdulla Avloni's son Kenja aka had been close friends with Olmas Umarbekov for many years. At the same time, there are speculations as to whether Olmas Umarbekov, Abulla Avloni and Mirkarimboys were related. Mirkarimboy had sons named Mirafzal, Mirsoat, Mirqosim, Mirsultan. Mirsoat Olmas married Umarbekov's aunt Zulfiya and became the groom of the Umarbekov family. That is, the Mirkarimboy family also had a good relationship with the Umarbek family. Since these three families in Mirabad district are related by marriage, it is possible that Abdulla Avloni's Kenja sons had a long-term friendship with Olmas Umarbekov, although they were related by kinship.

\section{CONCLUSION}

Although the Soviet system established itself as a scientific leader, it was forced to hide its ancestry, to renounce the suffixes in its name in order to survive repression, and to write its social origins as "working class." During the Soviet era, the field of genetics was denied in science. Large landowners, merchants, and intellectuals were persecuted as enemies of the people and forced to appear in works of art in a negative light. For example, the prototype of the image of Mirzakarimboy in Oybek's novel "Kutlug Kon" (Blessed Blood) was Mirkarimboy, one of the founders of Mirabad mahalla, Abdulla Avloni's family, who was an enlightened man who did a number of charitable deeds like the nobles of that time. Given that Abdulla Avloni changed his 
biography and hid his lineage, or the family tragedy of his first child, it is easy to imagine how dangerous the lives of writers who lived and worked in the Soviet era were. Most likely, the full name of Mirnematboy's grandson, Abdulla Avloni, the son of Miravlon, was Mirabdulla. In that case, "Mirabdulla Miravlon ogli" may be the full names of our writer.

\section{CONCLUSIONS}

Based on scientific analysis, it should be concluded that Abdulla Avloni is a descendant of one of the largest merchants of Tashkent and grew up in an extremely enlightened and educated family. He changed his biography out of compulsion at the request of the time. Although not repressed, Abdulla Avloni's work was unpopular with the Soviet system and his legacy had not been published or studied extensively enough for many years because the original essence of their works ran through enlightenment, patriotism, and freedom.

So, today it is time to objectively study the life, work and biography of all our writers, including Abdulla Avloni, who lived and worked in the Soviet era, in order to reveal the truth. It is necessary to directly identify the facts and evidences that are alien to our spirituality, our historical reality, which is compulsorily embedded in the works created during this period. We hope that as a result of our research, our researchers will find more obvious facts from the lives of our scientists.

\section{REFERENCES}

1. Abdulla Avloni. Selected works. From the series Heroes of Independence. Collected and prepared for publication by B. Kasimov. Volume 1. - Tashkent. Manaviyat. 2009.
2. “Manaviyat yulduzlari”. - Tashkent. Abdulla Qodiri National Heritage Publishing House. 1999.

3. Issues of national awakening and Uzbek philology. - Tashkent. University. 1993.

4. ziyo.uz

5. https://saviya.uz/hayot/tarjimai-hol/abdullaavloniy-1878-1934/?imlo=k

6. https://ziyouz.uz/ozbek-sheriyati/ozbekzamonaviy-sheriyati/abdulla-avloniy/

7. https://ziyouz.uz/ilm-va-fan/adabiyot/milliyuygonish/begali-qosimov-shuhrat-rizaevabdulla-avloniy-1878-1934/

8. https://arboblar.uz/uzkr/people/avloniabdulla

9. http://e-adabiyot.uz/kitoblar/malumot/220abdulla-avloniy.html

10. https://arboblar.uz/uzkr/people/kasymovbegali

11. https://shosh.uz/toshkentliklar-abdullaavloniy/ 